\title{
ETIKA LINGKUNGAN DAN IMPLEMENTASINYA DALAM PEMELIHARAAN LINGKUNGAN ALAM PADA MASYARAKAT KAMPUNG NAGA
}

\author{
Citra Nurkamilah \\ Fakultas Ushuluddin UIN Sunan Gunung Djati Bandung \\ Jl. AH. Nasution No. 105 Cibiru, Bandung, Jawa Barat, Indonesia \\ E-mail: Cytranurkamilah@gmail.com
}

\begin{abstract}
The environmental damage is the reflection of the disruption of the lungs of the earth (forest) result of the attitude of the human antroposentrik the exploit is excessive. To balance the natural environment so it will not be damaged is the regained human behavior or ethics that will save the environment. This ethic has been long applied in Kampung Naga which they have the alternative view of life regarding the human relation with the environment that considered sacred. The purpose of this research is to know about the environmental ethics in Kampung Naga in protecting their environment. This research uses descriptive qualitative method with anthropological and phenomenological approaches. The result of this research is every people in Kampung Naga has the environmental ethic that is quite intent by referring to values which formulated systematically based on inheritance ancestors, tangible inheritance and intangible inheritance. This has an impact of disaster mitigation (the efforts to reduce the risk) in Kampung Naga such as preventing landslides and floods, the maintenance of the integrity of the environment, the maintenance of the forest as the lungs of life, and every ecological creatures in that region also obeyed the ethic which presented by ekosentrisme and deep ecology. So, the environmental ethic in Kampung Naga shows about the balance of the ecological relation.
\end{abstract}

\section{Keywords:}

Ethic, Environment, Kampung Naga

\begin{abstract}
Abstrak
Kerusakan lingkungan alam merupakan cerminan dari terganggunya paru-paru bumi (Hutan) akibat dari sikap antroposentrik manusia yang mengeksploitasi secara berlebihan. Untuk menyeimbangkan lingkungan alam agar tidak semakin rusak yaitu menumbuhkan kembali perilaku atau etika manusia yang peduli terhadap lingkungan. Etika ini telah lama diterapkan di Kampung Naga yang mempunyai pandangan hidup secara alternatif mengenai hubungan manusia dengan lingkungan alam yang dianggap sakral. Penelitian ini bertujuan untuk memberikan gambaran secara umum mengenai etika lingkungan di Kampung Naga dalam menjaga lingkungan alam. Metode yang digunakan adalah metode kualitatif dengan pendekatan antropologis dan fenomenologis. Hasil dari penelitian ini yaitu masyarakat Kampung Naga memiliki etika lingkungan yang cukup intens dengan berpedoman pada nilainilai yang dirumuskan secara sistematis berdasarkan pada warisan nenek moyang (leluhur) yaitu warisan yang tampak dan warisan yang tidak tampak. Hal ini berdampak pada mitigasi (upaya mengurangi resiko) bencana di Kampung Naga seperti mencegah longsor dan banjir, terjaganya keutuhan sumber daya alam, terjaganya fungsi hutan yang merupakan paru-paru kehidupan, serta semua makhluk ekologis di wilayah adat tersebut telah samasama menaati etika yang disuguhkan oleh ekosentrisme atau deep ecology. Sehingga etika lingkungan di Kampung Naga mencerminkan hubungan ekologis yang seimbang.
\end{abstract}

Kata Kunci:

Etika, Lingkungan Alam, Kampung Naga.

\section{A. PENDAHULUAN}

Keadaan planet bumi yang berumur milyaran tahun bahkan lebih ini telah mengalami kecacatan lingkungan. Lingkungan alam, terutama hutan yang berfungsi sebagai penyeimbang alam telah gagal dikelola dengan baik oleh manusia. Manusia selalu mengabaikan kesehatan hutan di muka bumi ini dengan selalu mengeruk dan mengeksploitasi alam secara ganas. Padahal kesehatan hutan merupakan jaminan atau aset dari terpenuhinya kebutuhan manusia dalam waktu yang lama. Seperti halnya menyediakan $\mathrm{O}^{2}$ (oksigen) untuk manusia bernafas, menyimpan 
sumber air bersih, menyerap $\mathrm{CO}^{2}$ (karbondioksida), me-nyerap polusi udara, memproduksi P3 (pangan, papan, dan pakan), menyediakan berbagai macam obat herbal, dan lain sebagainya.

Melihat keadaan bumi yang semakin renta dan kerusakan lingkungan alam yang semakin nyata, muncullah beberapa peringatan secara global yang di peringati di setiap tahunnya. Seperti, "Hari Hutan Sedunia" yang diperingati setiap tanggal 21 Maret yang bertujuan untuk memperingatkan manusia tentang betapa pen-tingnya hutan untuk keberlangsungan hidup. "Hari Lingkungan Hidup" yang diperingati setiap tanggal 5 Juni yang bertujuan untuk memperingatkan manusia untuk berhati-hati dalam memanfaatkan sumber daya alam di bumi. Juga "Hari Bumi" yang diperingati setiap tanggal 22 April yang bertujuan untuk meningkatkan kesadaran dan cara pandang manusia terhadap kesehatan bumi.

Hal ini menegaskan bahwa laju kerusakan alam bukan hanya sekedar perhatian sekelompok aktivis lingkungan saja, melainkan juga menjadi perhatian seluruh lapisan masyarakat. Hal ini diperkuat oleh pernyataan Robert Borrong yang merupakan seorang aktivis lingkungan dan teolog, Ia memaparkan bahwa akhir-akhir ini perhatian masyarakat untuk menjaga dan memelihara kelestarian lingkungan memang semakin meningkat. Pernyataan tersebut sejalan dengan pengetahuan yang semakin banyak dan pengalaman yang semakin nyata bahwa saat ini lingkungan hidupnya atau bumi sedang sakit dan rusak. ${ }^{1}$

William Chang dalam bukunya yang berjudul "Moral Spesial" memaparkan bahwa masalah lingkungan pada umumnya terkait dengan krisis etika manusia dalam berhadapan dengan lingkungan alam. ${ }^{2}$ Dalam masyarakat beradab, etika menuntun manusia dalam meninjau kembali sejumlah gagasan yang

\footnotetext{
${ }^{1}$ Robert P. Borrong, Etika Lingkungan Hidup dan Perspektif Kristen, dalam Jurnal Pelita Zaman, Vol. 13 No.1, (Bandung: Yayasan Pengembangan Pelayanan Kristen, 1998), 8.

2 William Chang, Moral Spesial, (Yogyakarta: Kanisius, 2015), 277.
}

benar dan salah mengenai tingkah laku manusia terhadap alam. ${ }^{3}$ Sehingga pada dasarnya perilaku manusia yang menggambarkan benar atau salah maupun buruk atau baik serta sikap tanggung jawab yaitu produk dari analisis etika yang mencakup nilai dan moral dalam meng-hadapi segala sesuatu dikehidupannya.

Begitu pula, A. Sonny Keraf dalam bukunya "Etika Lingkungan Hidup" mengingatkan bahwa masalah lingkungan hidup adalah masa-lah moral manusia atau perilaku manusia. Lebih jauh lagi, Sonny Keraf $^{4}$ memaparkan bahwa:

Etika lingkungan hidup tidak hanya berbicara mengenai perilaku manusia terhadap alam, namun juga mengenai relasi di antara semua kehidupan alam semesta, yaitu antara manusia dengan manusia yang mempunyai dampak pada alam dan antara manusia dengan makhluk hidup lain atau dengan alam secara keseluruhan.

Kerusakan bukan masalah teknis tetapi krisis lingkungan adalah krisis moral manusia. Sehingga etika lingkungan digunakan sebagai cara merubah pandangan dan perilaku manusia terhadap lingkungan. Dalam hal ini terdapat beberapa teori yang dikenal dalam melihat hubungan manusia dengan alam yaitu teori antroposentrisme, biosentrisme dan ekosentris-me. ${ }^{5}$ Ketiga teori ini memiliki cara pandang yang berbeda tentang manusia dan alam, serta hubungan manusia dengan alam.

Antroposentrisme memaparkan bahwa hanya manusia yang berhak mendapat pertimbangan moral sedangkan makhluk lainnya hanya digunakan sebagai sarana dalam pencapaian berbagai macam tujuan manusia. ${ }^{6}$ Etika ini dianggap hanya berlaku bagi komunitas manusia, etika dalam aliran ini memandang bahwa manusia adalah pusat dari alam semesta, memiliki nilai lebih, dan alam dilihat hanya sebagai objek, alat, dan sarana bagi pemenuhan kebutuhan dan kepentingan manusia. ${ }^{7}$ Adanya kedudukan dan nilai moral

\footnotetext{
${ }^{3}$ Ibid, 279.

4 A. Sonny Keraf, Etika Lingkungan Hidup, (Jakarta: Kompas, 2010), 41-42.

${ }^{5}$ Ibid, 45.

${ }^{6}$ William Chang, Moral Spesial, 277.

${ }^{7}$ A. Sonny Keraf, Etika Lingkungan Hidup, 47.
} 
lingkungan hidup yang terpusat pada manusia (human centered ethic) mengakibatkan manusia bersikap antroposentrik. ${ }^{8}$ Yang pada akhirnya berakibat kepada ekploitasi lingkungan yang berlebihan.

Selanjutnya, paradigma mengenai etika lingkungan yang baru yakni etika biosentrisme dan etika ekosentrisme muncul guna untuk menanggapi paradigma etika sebelumnya yang menyatakan bahwa manusia sebagai pusat alam semesta serta yang mempunyai hak dalam menguasai alam semesta. ${ }^{9}$ Etika biosentrisme memiliki pandangan bahwa setiap kehidupan dan makhluk hidup mempunyai nilai dan ber-harga pada dirinya sendiri. Paham ini memiliki pokok-pokok pandangan sebagai berikut. Pertama, alam memiliki nilai pada dirinya sendiri (intrinsik) lepas dari kepentingan manusia. Kedua, alam diperlakukan sebagai moral, terlepas bagi manusia ia bermanfaat atau tidak, sebab alam adalah komunitas moral. Artinya, kehidupan di alam semesta ini akan di hormati seperti manusia menghormati sistem sosial yang terdapat dalam kehidupan mereka. ${ }^{10}$

Sedangkan Etika ekosentrisme memiliki pandangan lebih luas. Menurut paham ini, sama dengan biosentrisme, perjuangan penyelamat-an dan kepedulian terhadap lingkungan alam tidak hanya mengutamakan penghormatan atas spesies (makhluk hidup saja), melainkan perhatian setara atas seluruh kehidupan. Artinya etika ini berlaku pada keseluruhan komponen lingkungan, seluruh komunitas ekologis, baik yang hidup maupun mati. Ekosentrisme atau The Deep Ecology bertindak dalam dua ranah, yakni ranah praktis dan ranah filosofis. ${ }^{11}$ Dalam ranah praktis, artinya ranah ini di praktikan "hidup dalam tempat tinggal' dengan entropi dan gaya hidup mengkomsumsi yang sangat sedikit. Sedangkan dalam ranah filosofis, the deep ecology bisa disebut sebagai ecosophy yaitu kearifan yang mengatur kehidupan selaras

\footnotetext{
${ }^{8}$ William Chang, Moral Spesial, 286.

${ }^{9} \mathrm{Ibid}, 315$.

${ }^{10}$ Rachmad K. Dwi Susilo, Sosiologi Lingkungan, (Jakarta: Rajawali Pers, 2012), 100-101.

${ }^{11}$ Ibid., 116-117.
}

dengan alam sebagai rumah tangga dalam arti luas.

Dengan demikian, etika biosentrisme dan ekosentrisme menekankan bahwa manusia dan makhluk lainnya mempunyai hak dan nilai yang sama. Dan apa yang menjadi inti dari etika biosentrisme dan ekosentrime bisa jadi sudah di praktikan oleh suku asli (masyarakat adat) di seluruh dunia, termasuk Indonesia.

Hal ini tercermin dalam praktik pengelolaan dan pelestarian alam yang termanifestasikan oleh adanya kawasan suci atau sakral pada masyarakat adat. Kawasan suci atau sakral tersebut berupa hutan keramat dan hutan larangan yang dijaga dengan baik oleh masya-rakatnya, yang pantang dimasuki dan dirusak. Keyakinan terhadap pemeliharaan hutan di wilayah adat merupakan hasil dari ketaatan mereka terhadap warisan dan amanat nenek moyang. Tentu saja, kondisi hutan pada kawasan masyarakat adat menjadi salah satu contoh dari etika dan perilaku masyarakatnya dalam menilai hutan yang telah lama dipertahankan. Dan hal ini termasuk kedalam upaya konservasi hutan yang tidak banyak dilakukan oleh masyarakat modern.

Masyarakat Kampung Naga merupakan salah satu masyarakat adat yang berada di Jawa Barat, yang secara administrasi berada di wilayah Desa Negalsari, Kecamatan Salawu, Kabupaten Tasikmalaya. Masyarakat ini telah lama hidup berdampingan dengan alam. Dimana sumber ajaran yang mereka anut masih sesuai dengan ajaran nenek moyang. Dalam masyarakat Kampung Naga tedapat pula kawasan hutan keramat dan hutan larangan yang secara sadar atau tidak telah memberi dampak positif pada pelestarian lingkungan di Kampung Naga.

Hubungan harmonis antara manusia dan lingkungan yang ditunjukkan oleh masyarakat adat merupakan tamparan bagi masyarakat modern saat ini. Kiranya, teori biosentrisme dan ekosentrisme (deep ecology) yang mengajak manusia untuk meninggalkan sikap antroposentrik telah terlembaga di kearifan lokal tradisional selama ini. Rachmad K. Dwi Susilo pun menegaskan bahwa 
membangkitkan kearifan-kearifan lokal merupakan salah satu cara menjaga lingkungan dan meredam watak eksploitatif manusia atas alam. ${ }^{12}$

Berdasarkan uraian diatas, penulis tertarik untuk menelusuri lebih dalam tentang penyikapan masyarakat Kampung Naga terhadap lingkungan alam yang tidak luput dari etika lingkungan yang dilakukan masyarakat adat Kampung Naga. Dimana fokus dalam penelitian ini yaitu bagaimana konsep etika lingkungan dalam perspektif masyarakat Kampung Naga? Serta bagaimana wujud dari penerapan etika lingkungan pada masyarakat Kampung Naga.

Dalam menelusuri penerapan etika lingkungan masyarakat adat Kampung Naga, penulis menggunakan metode kualitatif dengan pendekatan secara antropologis dan fenomenologis. Pendekatan antropologis pada umumnya sebagai dasar filosofis yang fokus bahasannya berkaitan erat dengan kegiatan manusia, baik secara normative maupun historis. Unit analisisnya bisa berupa individu, kelompok/organisasi/masyarakat, benda-benda sejarah, buku, dan cerita-cerita rakyat. ${ }^{13}$ Sedangkan pendekatan fenomenologis lebih kepada kebenaran sesuatu dapat diperoleh melalui cara menagkap fenomena atau gejala yang memancar dari objek yang diteliti tanpa ada suatu penilaian dari peneliti. Penggunaan pendekatan antropologi adalah karena masyarakat adat Kampung Naga memiliki kearifan lokal yang masih dilaksanakan dan dipertahankan, terlebih dalam menjaga keseimbangan alam. Sedangkan pendekatan fenomenologi karena peneliti akan menangkap gejala atau fenomena yang terjadi pada masyarakat adat Kampung Naga, khususnya mengenai kelestarian lingkungan alam.

\section{B. HASIL DAN PEMBAHASAN}

\section{Etika Lingkungan Masyarakat Kampung Naga}

Masyarakat Kampung Naga merupakan masyarakat adat atau tradisional yang

\footnotetext{
${ }^{12} \mathrm{Ibid}, 163$.

${ }^{13}$ Imam Suprayogo dan Tobroni, Metodologi Penelitian Sosial Agama, (Bandung: Remaja Rosdakarya, 2003), 63.
}

termasuk ke dalam masyarakat yang homogen. Artinya, masyarakat yang diyakini sebagai satu keturunan nenek moyang (leluhur) dan hanya memiliki keyakinan yang kuat terhadap amanat nenek moyang. Kampung Naga ini terletak di Kabupaten Tasikmalaya Jawa Barat. Kawasan yang masih kental dengan ajaran tersebut seringkali disebut dengan istilah kawasan adat atau kawasan masyarakat adat. Kini, kawasan Kampung Naga telah menjadi daya tarik bagi warga lokal maupun warga asing yang ingin tahu lebih dalam mengenai keanekaragaman budaya yang ada di Indonesia. Dengan begitu Kampung Naga ini telah resmi menjadi salah satu cagar budaya dan pariwisata di provinsi Jawa Barat.

Pemahaman etika lingkungan pada masyarakat Kampung Naga, kiranya akan sedikit menyinggung kebudayaan sunda yang secara tidak langsung memiliki hubungan dengan pembahasan etika lingkungan di wilayah Kampung Naga.

Dalam budaya sunda, istilah ciri sabumi cara sadesa memiliki arti di setiap lingkungan terdapat ciri dan cara yang khas serta mempengaruhi perilaku para penghuninya. ${ }^{14}$ Ciri khas atau identitas tersebut merupakan hasil dari kesepakatan secara kolektif yang lazimnya dipelihara serta dikembangkan secara turun temurun. Identitas itu pula yang nantinya akan mempengaruhi kehidupan masyarakat di kawasan tersebut yang akan mempertegas identitas budayanya

Masyarakat Kampung Naga merupakan bagian dari masyarakat sunda yang memiliki ciri khas dan cara khas serta memperkaya budaya sunda. Ciri khas pada masyarakat Kampung Naga tidak terlepas dari sistem pengetahuan lokal yang mereka terapkan berdasarkan warisan nenek moyang dan telah disepakati oleh seluruh warganya untuk tetap dilestarikan. Salah satu ciri yang membedakan masyarakat Kampung Naga dengan masyarakat di perkotaan adalah hidup mereka yang telah lama selaras dengan alam, hidup berdampingan dengan alam, dan bersahabat

${ }^{14}$ Hawe Setiawan, Tanah Dan Air Sunda, (Depok: Api Kecil, 2017), 23. 
dengan alam. Mereka telah memperlihatkan bahwa kelangsungan budaya dan lingkungan sama pentingnya.

Alam atau lingkungan dalam pandangan masyarakat Kampung Naga merupakan suatu hal yang telah dijaga dan diamanatkan oleh para leluhur kepada generasi selanjutnya demi menjaga keberlangsungan hidup yang baik, yang juga sekaligus merupakan ciptaan Gusti Allah yang harus dipelihara. ${ }^{15}$ Selain itu, lingkungan Kampung Naga diyakini sebagai tanah warisan para leluhur atau karuhun untuk anak cucunya yang wajib dijaga dan dilestarikan. Dengan begitu, pemahaman etika lingkungan pada masyarakat Kampung Naga tidak terlepas dari kepercayaan mereka terhadap roh nenek moyang (karuhun) untuk selalu menjaga lingkungan yang telah menjadi warisan secara turun temurun.

Lebih jauh lagi, Lingkungan alam pada masyarakat Kampung Naga bukan hanya sebagai lingkungan yang profan, melainkan juga sebagai lingkungan yang sakral. Artinya, Masyarakat Kampung Naga selaras dengan alam dalam hal lingkungan profan mencerminkan bahwa masyarakat Kampung Naga termasuk kedalam suatu komponen ekosistem yang berinteraksi dengan komponen alam lainnya, baik dengan komponen hayati ataupun komponen fisik yang dibentuk melalui etika lingkungan dari sisi adat atau hukum adat.

Sedangkan masyarakat Kampung Naga selaras dengan alam dalam hal lingkungan sakral terceminkan dari masyarakat yang menghormati sifat-sifat alam melalui upacaraupacara mitis sakral dalam pemeliharaan lingkungan alam yang telah dicontohkan oleh nenek moyang. Selain itu, hubungan masyarakat Kampung Naga dengan lingkungan sakral ini dilakukan sebagai upaya penghormatan kepada nenek moyang dan makhluk gaib yang menempati lingkungan alam atau tempattempat tertentu di Kampung Naga. ${ }^{16}$ Interaksi

${ }^{15}$ Endut (Masyarakat Kampung Naga), wawancara oleh Citra, Kampung Naga Tasikmalaya, Tanggal 17 Juli 2017.

${ }^{16}$ Uron (Ketua RT Kampung Naga), wawancara oleh Citra, Kampung Naga Tasikmalaya, Tanggal 17 Juli 2017. ini mencerminkan terjadinya hubungan ekologis dan teologis di Kampung Naga.

Upaya konseptualisasi etika lingkungan di Kampung Naga merupakan bagian integral dari kerangka dalam menjelaskan atau menggam-barkan budaya ekologis dalam komunitas adat di Kampung Naga. Konsep etika lingkungan pada masyarakat Kampung Naga merujuk pada nilai kepercayaan dan warisan nenek moyang yang telah lama diterapkan. Masyarakat Kam-pung Naga memahami bahwa etika lingkungan yang telah lama mereka terapkan secara turun temurun tersebut memiliki beribu manfaat bagi masa depan kawasan yang mereka tempati.

Konsep atau sumber etika lingkungan yang merujuk pada warisan nenek moyang (karuhun atau leluhur) di Kampung Naga terbagi menjadi dua bagian, yaitu Pertama, sumber eti-ka lingkungan yang berasal dari warisan nenek moyang yang tampak (tangiable). Kedua, sumber etika lingkungan yang berasal dari warisan nenek moyang yang tidak tampak (intangiable).

\section{a. Sumber Etika Lingkungan Yang tampak (tangible)}

Sumber etika lingkungan ini merupakan warisan nenek moyang di Kampung Naga yang terlihat dan diwujudkan dalam beberapa bentuk yang pro terhadap pemeliharaan lingkungan alam di kawasannya. Sumber etika ini bisa kita lihat secara langsung saat pertama kali ber-kunjung ke dalam pemukiman Kampung Naga. Beberapa bentuk warisan tersebut dikategori-kan menjadi tiga bagian, yaitu:

\section{1) Dalam Bentuk Bangunan Atau Gaya Arsitektur Rumah}

a. Bentuk rumah yang selaras di Kampung Naga menjadi suatu aturan adat yang harus ditaati oleh warganya dan sudah disepakati secara kolektif. Aturan adat ini menggambar-kan bahwa rumah di Kampung Naga mem-punyai unsur-unsur kepercayaan dan pemakna-an tersendiri bagi masyarakatnya. Mereka meyakini bahwa bentuk bangunan yang seder-hana ini telah dipertimbangkan dan ditentukan 
oleh nenek moyang (leluhur) mereka demi kebaikan para anak cucunya kelak, karena mereka berkeyakinan bahwa tidak ada orang tua yang akan mencelakakan generasinya. ${ }^{17}$

b. Pewarisan aturan dalam bentuk bangunan di Kampung Naga merupakan etika lingkungan yang tepat, juga merupakan wujud dari ke-budayaan fisik yang disakralkan oleh masyara-katnya. Hal ini terbukti dengan cara mereka meletakkan bangunan dengan arah yang sama, mengikuti kontur tanah yang ada dan meng-gunakan material dari bahan natural atau alami seperti kayu, injuk, bambu, dan batu yang se-benarnya menggambarkan mereka telah me-nyatu dengan alam, ramah lingkungan, dan selaras dengan alam. Kesederhanaan wujud dari bangunan Kampung Naga mengisyaratkan hubungan yang baik antara masyarakat Kampung Naga dengan lingkungan alamnya dan membuat citra lingkungan Kampung Naga menjadi asri dan lestari.

c. Lebih jauh lagi, Kuncen Kampung Naga menggambarkan filosofi arsitektur rumah di Kampung Naga seperti tubuh manusia yang memiliki kepala, tubuh, dan kaki. Atap yang terbuat dari injuk diibaratkan kepala manusia, bangunan dari kayu dan bilik diibaratkan badan, dan batu penyangga diibaratkan kaki. ${ }^{18}$ Sehingga dengan pemikiran tersebut masyarakat Kampung Naga tetap menjaga bangunan rumah tersebut sebagaimana merawat tubuh mereka sendiri.

\section{2) Bentuk Tata Wilayah}

d. Bentuk penataan wilayah di kawasan adat telah lama ada dan turun temurun. Dalam hal ini, tata wilayah di Kampung Naga terbagi menjadi tiga bagian, yaitu wilayah atas (sakral), wilayah

17 Endut (Masyarakat Kampung Naga), wawancara oleh Citra, Kampung Naga Tasikmalaya, Tanggal 17 Juli 2017.

${ }^{18}$ Ade Suherlin (Kuncen Kampung Naga), wawancara oleh Citra, Kampung Naga Tasikmaaya, Tanggal 21 Juli 2017. tengah (netral), dan wilayah bawah (kotor). Pembagian wilayah ini memiliki makna dan nilai yang berhubungan dengan pe-mahaman masyarakat Kampung Naga terhadap etika lingkungan, yakni cara menjaga hubung-an masyarakat Kampung Naga dengan alam dan hubungan masyarakat Kampung Naga dengan nenek moyang (leluhur).

e. Untuk lebih jelasnya, konsep dari kosmologi Kampung Naga yang terbagi men-jadi tiga wilayah tersebut akan lebih dijelaskan secara rinci sebagai berikut:

f. Pertama, Kawasan atas (sakral) di Kampung Naga. Wilayah yang disakralkan oleh masyarakat Kampung Naga merupakan wilayah yang memiliki aturan adat untuk tidak dimasuki oleh sembarang orang dan tidak boleh mengambil apapun didalamnya termasuk ranting pohon yang berjatuhan. ${ }^{19}$ Orang yang dapat memasuki wilayah ini hanyalah kuncen Kampung Naga saat melaksanakan upacara adat saja. Wilayah yang disakralkan ini terletak di atas bukit di bagian barat Kampung Naga yang berupa hutan keramat. Aturan adat semacam ini bukan hanya untuk menghormati nenek moyang saja melainkan juga cara menghormati lingkungan alam dan konservasi lingkungan alam. Karena secara real, hutan keramat ini berada diatas kawasan pemukiman Kampung Naga yang berperan sebagai hutan lindung yang akan melindungi kawasan dibawahnya. Hutan inilah yang berperan sebagai penyerap air hujan sehingga tidak mengakibatkan banjir ke wilayah bawah atau pemukiman warga.

$$
\text { g. Kedua, kawasan tengah }
$$

(Netral) di Kampung Naga. Kawasan ini berada ditengah-tengah wilayah. Wilayah tengah ini menjadi pusat kehidupan masyarakat Kampung Naga. Di wilayah ini mereka melaksanakan berbagai macam

${ }^{19}$ Endut (Masyarakat Kampung Naga), wawancara oleh Citra, Kampung Naga Tasikmalaya, Tanggal 17 Juli 2017. 
aktivitas disetiap harinya, wilayah untuk bernaung, dan bercocok tanam. Istilah netral pada wilayah ini diartikan sebagai wila-yah yang bersih dan bisa menjadi tempat yang suci. Pada wilayah ini terdapat berbagai macam bangunan diantaranya bumi patamon yang digunakan setiap acara adat, rumah warga yang digunakan untuk tempat tinggal, mesjid yang digunakan untuk melaksanakan ibadah dan ritual adat, dan tempat-tempat peninggalan nenek moyang yang berupa bumi ageung; patilasan pangsolatan; dan lumbungan. $^{20}$ Selain itu, salah satu masyarakat Kampung Naga menceritakan bahwa di kawasan netral pun terdapat sumber daya alam berupa mata air yang terletak di sebelah selatan Kampung Naga. Mereka mengatakan bahwa air tersebut dapat langsung diminum dan digunakan untuk keperluan persediaan air bersih untuk makan dan minum masyarakatnya. Mereka meyakini bahwa air ini jernih dan memiliki khasiat yang baik untuk kesehatan tubuh. Lebih lanjut ia memaparkan bahwa sumber air ini tidak pernah kering sehingga masyarakat Kampung Naga tidak pernah kekurangan air minum atau air bersih. ${ }^{21}$

h. Ketiga, kawasan bawah (Kotor) di Kampung Naga. Wilayah ini yang pertama kali akan terlihat oleh pengunjung, karena wilayah ini berada di permukaan tanah yang lebih rendah. Batas wilayah bawah dan netral adalah pagar yang terbuat dari bambu. Di wilayah ini masyarakat Kampung Naga melaksanakan kegiatan penunjang seperti mandi, buang air kecil, buang air besar, menumbuk padi, memelihara ikan, dan memelihara ternak. Sehingga pada wilayah ini akan ditemukan bangunan MCK, kamar mandi, kolam ikan, kandang ternak, dan saung lisung.

${ }^{20}$ Uron (Ketua RT Kampung Naga), wawancara oleh Citra, Kampung Naga Tasikmalaya, Tanggal 17 Juli 2017.

${ }^{21}$ Endut (Masyarakat Kampung Naga), wawancara oleh Citra, Kampung Naga Tasikmalaya, Tanggal 17 Juli 2017.
Diseberang kawasan bawah ini terdapat sungai ciwulan yang berdekatan dengan hutan larangan. ${ }^{22}$

3) Penghormatan Terhadap Alam Yang Disakralkan Dan Harus Dihindari Yaitu Hutan Keramat Dan Hutan Larangan.

Warisan ini menjadi etika yang digunakan oleh masyarakat adat dalam memelihara hutan yang ada di wilayah adatnya. Selain menjadi sebuah etika, warisan ini menjadi aturan yang harus dilestarikan oleh semua masyarakat adat Kampung Naga maupun Sanaga.

Pada wilayah adat Kampung Naga penghormatan terhadap alam yang disakralkan termanifestasikan oleh Hutan Keramat. Hutan ini merupakan tempat pemakaman jasad para nenek moyang (leluhur) yang dipandang oleh mereka sebagai sentral kekuatan baik di Kampung Naga. Selain itu, penghormatan lain terhadap alam yang disakaralkan yaitu termanifestasikan oleh bumi ageung (tempat menyimpan benda-benda pusaka milik adat), bumi pasolatan, dan lumbungan (bekas tempat penyimpanan padi) yang berada di wilayah pemukinan Kampung Naga dengan ditandai oleh pagar bambu disekelilingnya. ${ }^{23}$

Sedangkan terkait dengan penghormatan terhadap alam yang harus dihindari termanifestasikan oleh Hutan Larangan. Hutan larangan ini diyakini oleh masyarakat Kampung Naga sebagai hutan yang ditempati oleh kekuatan jahat, mereka meyakini hutan larangan ini sentral dari para dedemit atau roh jahat. Artinya, di dalam hutan tersebut terdapat penunggu yang tidak terima jika habitatnya diganggu. Sehingga hutan ini mesti dijauhi oleh masyarakat sekitar. Meskipun terdapat ranting yang jatuh atau pohon yang tumbang tidak ada satupun yang berani untuk me-ngambil ranting tersebut. Masyarakat Kam-pung Naga mengatakan bahwa "lebih baik membeli kayu bakar saja ketimbang

${ }^{22}$ Heri (Masyarakat Kampung Naga), wawancara oleh Citra, Kampung Naga Tasikmalaya, Tanggal 21 Juli 2017.

${ }^{23}$ Uron (Ketua RT Kampung Naga), wawancara oleh Citra, Kampung Naga Tasikmalaya, Tanggal 17 Juli 2017. 
mengam-bil kayu yang jatuh di Hutan Larangan tersebut". ${ }^{24}$

\section{b. Sumber Etika Lingkungan Yang Tidak Tampak (intangible)}

Sumber etika lingkungan ini merupakan warisan nenek moyang di Kampung Naga yang tidak terlihat secara langsung melainkan diwujudkan dalam bentuk pantangan atau tabu (pamali atau teuwasa), pikukuh dan pengetahuan yang disampaikan secara lisan, turun temurun dari satu generasi ke generasi selanjutnya, serta pengetahuan yang berkenaan dengan alam. Adapun secara lebih rinci dapat dilihat dalam penjelasan berikut.

\section{i. Pantangan Atau Tabu}

Pantangan atau tabu merupakan warisan nenek moyang di Kampung Naga yang tak nampak, pantangan ini pun yang menjadikan masyarakat Kampung Naga berhati-hati dalam tindakan mereka sehari-hari. Pantangan atau tabu ini menjadi salah satu prinsip dalam pengelolaan lingkungan alam disana. Masyarakat Kampung Naga sangat menghormati nenek moyang yang telah memberi ajaran untuk bersatu dengan alam. Dalam hal ini, mereka meyakini bahwa pantangan yang diajarkan nenek moyang sebenarnya demi keseimbangan lingkungan alam yang mereka tinggali. Selain itu, pantangan atau tabu diyakini senantiasa dikaitkan dengan hal-hal yang bersifat sakral (kekuatan yang berasal dari alam ghaib dan berbau mistis).

Adapun pantangan dalam hal lingkungan di Kampung Naga tersebut diantaranya adalah: ${ }^{25}$

a) Pantangana memasuki hutan larangan, menebang pohon, mengambil ranting yang jatuh, serta mengambil sesuatu di dalam hutan larangan.

b) Pantangan memasuki hutan keramat, menebang pohon, mengambil ranting yang jatuh, serta mengambil sesuatu di dalam hutan keramat.

${ }^{24}$ Endut (Masyarakat Kampung Naga), wawancara oleh Citra, Kampung Naga Tasikmalaya, Tanggal 17 Juli 2017.

${ }^{25}$ Endut (Masyarakat Kampung Naga), wawancara oleh Citra, Kampung Naga Tasikmalaya, Tanggal 17 Juli 2017. c) Pantangan membuat rumah bangunan dari bahan material. Artinya di Kampung Naga sangat tabu jika mengubah apapun amanat dari nenek moyang, baik dalam lingkungan alam ataupun bentuk bangunan di wilayahnya.

\section{j. Pikukuh}

Pikukuh merupakan salah satu warisan nenek moyang dalam bentuk yang tak nampak dan diyakini sebagai suatu doktrin dalam menjalankan kehidupan di Kampung Naga. Pikukuh nenek moyang disampaikan melalui lisan dari para leluhurnya kepada penerusnya, sehingga mereka diwajibkan taat dalam memegang teguh pikukuh nenek moyang tersebut, baik itu masyarakat Kampung Naga ataupun Sanaga. Pikukuh nenek moyang tersebut antara lain mewajibkan untuk: ${ }^{26}$

a) Memelihara dan menjaga alam yang tertuang dalam istilah "leuweung lain ruksakeun tapi rawateun jeung rumateun".

b) Memelihara warisan nenek moyang yang tertuang dalam istilah "alam jeung jaman kaulaan saur elingkeun" yang mem-punyai arti zaman modern tetap diamini dan warisan budaya tetap dijalankan serta dipertahankan.

c) Menyelenggarakan dan menghormati upacara-upacara adat, seperti upacara Hajat Sasih, upacara menyepi dan upacara lainnya yang dilakukan oleh nenek moyang.

Dasar inilah yang melekat pada masyarakat Kampung Naga yang mengandung arti bahwa lingkungan alam tidak boleh semena-mena dirusak serta masyarakat tidak mudah tergoyah oleh perubahan zaman karena senantiasa patuh pada adat istiadat yang dipegangnya.

\section{k. Pengetahuan Mengenai Lingkungan}

${ }^{26}$ Endut (Masyarakat Kampung Naga), wawancara oleh Citra, Kampung Naga Tasikmalaya, Tanggal 17 Juli 2017. 
Pengetahuan mengenai lingkungan masyarakat Kampung Naga merupakan warisan yang diberikan oleh nenek moyangnya secara lisan dan praktek. Pengetahuan ini sudah sejak dulu dilakukan oleh nenek moyang mereka sehingga turun kepada anak cucunya. Interaksi langsung terhadap lingkungan alam sejak lama inilah yang membentuk pengetahuan dalam ber-interaksi dengan alam, karena mereka telah ter-biasa melihat dan merasakan keadiankejadian dan dampak dari setiap interaksi yang mereka lakukan. ${ }^{27}$

Sementara itu, Siti Maria dalam tulisannya mengelompokan pengetahuan tentang lingkungan alam di Kampung Naga menjadi empat bagian, yaitu pengetahuan mengenai gejalagejala alam, pengetahuan tentang lingkungan flora, pengetahuan tentang fauna, dan pengetahuan mengenai lingkungan fisik. ${ }^{28}$

Pengetahuan mengenai gejala-gejala alam di Kampung Naga berasal dari kebutuhan praktis untuk bertani, berkebun, dan lain-lain. di mana pengetahuan tersebut berdasarkan pengamatan dan pengalaman mereka tentang pergantian musim penghujan atau kemarau. Sedangkan salah satu pengetahuan lingkungan fauna di Kampung Naga yang paling dasar adalah mengenai pertanian, yang mana masyarakat Kampung Naga dapat dengan baik mengelola padi mereka.

Adapun pengetahuan lokal mengenai tanaman pada masyarakat Kampung Naga yang bisa di jadikan obat herbal yang disebutkan oleh salah satu narasumber adalah obat pereda sakit haid atau orang Kampung Naga me-nyebutnya "kekeleun". Obat pereda sakit haid terbuat dari daun pucuk alpukat dan daun pecah beling, takaran dalam membuat obat tersebut disesuaikan dengan hari kelahiran orang yang bersangkutan. Misalnya jika orang yang sedang sakit haid tersebut dilahirkan pada hari minggu maka hanya dibutuhkan 5 helai pucuk alpukat dan 5 pucuk

27 Siti Maria Dkk, Sistem Keyakinan Pada Masyarakat Kampung Naga Dalam Mengelola Lingkungan Hidup: Studi Tentang Pantangan Dan Larangan, (Jakarta: Depdikbud, 1995), 34.

${ }^{28} \mathrm{Ibid}, 35$ daun pecah beling, setelah itu daun tersebut di rebus dengan air panas. ${ }^{29}$

Selain itu, dalam tulisan Siti Maria terdapat tumbuh-tumbuhan yang digunakan dalam upacara atau ritual adat, misalnya ketika melaksanakan ritual pertanian, masyarakat Kampung Naga ketika menancapkan benih padi, ditandai dengan daun hanjuang dan pucuk daun jambe yang dirangkapkan, dan ketika padi mulai mereka sesajen yang digunakan adalah pete besar, kelapa, ketimun, pucuk kawung, dan buah-buahan. ${ }^{30}$

Lebih lanjut, pengetahuan masyarakat adat terhadap lingkungan fauna digunakan dalam bidang pertanian juga. Masyarakat Kampung Naga harus mengetahui bagaimana hewan peliharaan harus diperlakukan agar dapat menjaga sawah mereka. Sedangkan pengetahuan mengenai lingkungan fisik tercermin dari pengetahuan masyarakatnya mengenai sungai, udara, air, rumah, dan lain sebagainya. Pengetahuan ini telah lama ada di Kampung Naga. Hal ini terbukti dengan terbentuknya penataan lingkungan dan penataan lahan perkampungan mereka serta bagaimana cara menata dan mengatur tata tertib hidup masyarakat dengan menyesuaikan kondisi alam sekitarnya. ${ }^{31}$

Dengan demikian, dapat dinyatakan bahwa konsep dan pemahaman etika lingkungan di Kampung Naga dijelaskan dari kesadaran, kearifan, dan kepedulian lingkungan yang menjadi integral dari kepercayaan masyarakat Kampung Naga sebagai komunitas adat yang ada di Tasikmalaya. Kesadaran, kearifan, dan kepedulian terhadap lingkungan tersebut mem-buktikan bahwa pemecahan masalah ling-kungan akan didapatkan di masyarakat yang masih memegang adat istiadat nenek moyang atau masyarakat adat yang mempunyai pan-dangan yang alternatif mengenai hubungan manusia dengan

\footnotetext{
${ }^{29}$ Endut (Masyarakat Kampung Naga), wawancara oleh Citra, Kampung Naga Tasikmalaya, Tanggal 17 Juli 2017.

30 Siti Maria dkk, Sistem Keyakinan Pada Masyarakat Kampung Naga Dalam Mengelola Lingkungan Hidup: Studi Tentang Pantangan Dan Larangan,41-42.

${ }^{31}$ Ibid, 43
} 
lingkungan alam. Pandangan alternatif tersebut berupa pengajaran dari nenek moyang mengenai lingkungan alam di wilayahnya.

Berdasarkan hal tersebut, jika dikaitkan dengan teori etika lingkungan secara umum. Masyarakat Kampung Naga akan terhindar dari rasa percaya diri manusia yang berlebihan yang termasuk pada istilah antroposentrisme. Kare-na mereka tidak menganggap bahwa mereka lebih tinggi dari lingkungan alam. Masyarakat Kampung Naga lebih menitikberatkan ke-hidupan yang tidak akan merugikan alamnya atau dengan kata lain menyatu dengan alam yang termasuk kedalam paham biosentrisme juga ekosentrisme yang termasuk kedalam aspek hubungan manusia dengan alam yang selaras. ${ }^{32}$

\section{Implementasi Pemahaman Etika Lingkungan dalam Pemeliharaan Lingkungan Alam di Kampung Naga}

1. Implementasi diartikan sebagai pelaksanaan atau penerapan. Bentuk kata kerjanya adalah mengimplikasikan yang artinya melaksanakan atau menerapkan. Dari hasil wawancara diperoleh informasi bahwa masyarakat Kam-pung Naga jelas telah lama hidup berdamping-an dengan alam. Berdasarkan pengetahuan lokal mereka dan prakteknya pun sangatlah singkron. Contohnya saja pengetahuan mereka terhadap warisan nenek moyang dalam beberapa pantangan, dipraktekkan di kehidu-pan nyata dengan tidak melanggarnya.

m. Selain itu, dalam prakteknya mereka sudah mengenal berbagai cara memanfaatkan sumber daya alam secara berkelanjutan yang terekam dalam kearifan lingkungan yang mereka pegang. Kearifan lingkungan ini merupakan implikasi dari pemahaman etika lingkungan perspektif masyarakat tradisional. Mereka mewujudkan pemahaman tersebut ke dalam tatanan lingkungan yang harmoni. Artinya, implementasi etika lingkungan di

32 Heri (Masyarakat Kampung Naga), wawancara oleh Citra, Kampung Naga Tasikmalaya, Tanggal 21 Juli 2017.
Kampung Naga berarti penerapan berbagai macam warisan nenek moyang pada lingkungan alam sehingga akan terhindar dari berbagai bencana alam yang tidak diinginkan.

n. Hal yang menjadi point utama dari etika lingkungan alam di Kampung Naga adalah adanya pikukuh nenek moyang yang dituang-kan ke dalam bahasa Sunda yang berbunyi "leuweung lain ruksakeun tapi rumateun jeung rawateun" 33 yang memberikan pesan yang sentral di Kampung Naga dalam menjaga dan memelihara lingkungan alam. Pikukuh menjadi pesan moral di Kampung Naga yang mem-pengaruhi perilaku masyarakat dalam menghadapi lingkungan alam.

o. Lebih tegas lagi, di Kampung Naga yang mempunyai ketentuan adat berupa "Pamali" menguatkan pikukuh yang telah disebutkan di atas bagi masyarakat Kampung Naga untuk tetap menjaga keseimbangan lingkungan alam di kawasan adat yang mereka tempati. ${ }^{34}$

p. Adanya hukum adat yang mengatakan untuk tidak memasuki hutan keramat yang kebetulan berada di atas pemukiman tersebut menjadikan hutan tersebut tetap terjaga fungsinya. Yang mana sangat banyak sekali fungsi hutan bagi keberlangsungan hidup manusia, diantaranya sebagai tempat untuk menyerap air, meng-hasilkan oksigen, penyedia sumber air, tempat hidup flora dan fauna, juga salah satu ekosistem yang menjadi penyeimbang dan pencegahan terhadap pemanasan global. Artinya, pemahaman dalam menjaga hutan di Kampung Naga yang awalnya hanya untuk menghormati nenek moyang menjadi cara jitu bagi masyarakat Kampung Naga yang juga memberi manfaat dalam menjaga

${ }^{32}$ Endut (Masyarakat Kampung Naga), wawancara oleh Citra, Kampung Naga Tasikmalaya, Tanggal 17 Juli 2017.

${ }^{34}$ Endut (Masyarakat Kampung Naga), wawancara oleh Citra, Kampung Naga Tasikmalaya, Tanggal 17 Juli 2017. 
keseimbang-an alam. Salah satu masyarakat Kampung Naga mengatakan:

q. Tidak bisa terbayangkan jika kami semua membawa ranting, menebang pohon di hutan larangan dan hutan keramat dengan seenaknya hanya untuk kebutuhan memasak yang menyebabkan kawasan hutan menjadi gundul. Maka kemungkinan besar wilayah Kampung Naga akan lenyap dan bencana akan sering terjadi di Kampung Naga. Kami sangat bersyukur kepada nenek moyang kami karena telah memberikan contoh dan aturan dalam menjaga hutan tersebut, hal ini sangat menentukan keberlangsungan hidup di wilayah Kampung Naga". 35

r. Selain itu, pemahaman etika lingkungan yang tertuang dalam tata wilayah dan bentuk bangunan di Kampung Naga merupakan salah satu cara memproteksi lingkungan dari ben-cana dan pengaruh luar. Tata ruang di Kam-pung Naga yang terbagi menjadi tiga bagian mempunyai konservasi berkelanjutan. Serta bentuk bangunan yang tidak pernah berubah dan memakai bahan alami sangat berpengaruh pada keadaan lingkungan alam di Kampung Naga. Tata wilayah yang termanifestasikan wilayah atas, tengah dan bawah, serta kawasan permukiman yang tertata dari atas sampai bawah inilah berdampak pada lestarinya lingkungan alam.

s. Bentuk dan posisi bangunan di Kampung Naga sangat memperhatikan dampak kedepan-nya. Masyarakat Kampung Naga meyakini jika posisi rumah mereka tidak mengikuti aturan dari nenek moyang maka akan terjadi banjir, karena pada dasarnya dengan posisi tersebut akan mempermudah jalan air hujan saat hujan deras. Air hujan tersebut akan mengalir secara gravitasi melalui lorong antar bangunan yang memanjang menuju ke sungai Ciwulan yang merupakan kawasan paling bawah di Kampung Naga. Meskipun sungai Ciwulan sedang meluap sekalipun, air tidak akan

35 Heri (Masyarakat Kampung Naga), wawancara oleh Citra, Kampung Naga Tasikmalaya, Tanggal 21 Juli 2017. masuk ke wilayah tengah yang merupakan pemukiman masyarakat kampung Naga karena air telah tersaring oleh kawasan bawah yang merupakan kolam di luar wilayah pemukiman. ${ }^{36}$

t. Begitu juga dengan aturan dalam bentuk atau gaya dari bangunan yang ada di Kampung Naga, mereka meyakini bahwa hal tersebut akan sangat membantu saat terjadi gempa bumi. Endut yang merupakan masyarakat Kampung Naga mengatatakan bahwa "Jika terjadi gempa bumi maka pemukiman kami tidak akan mudah rusak, karena bangunan kami tidak langsung menancap ke tanah". ${ }^{37}$

u. Hal tersebutlah salah satu contoh wujud dari penerapan etika lingkungan yang berbasis aturan adat dalam memelihara lingkungan alam di wilayah Kampung Naga. Sehingga sampai saat ini wilayah adat Kampung Naga masih utuh meskipun berada di lembah yang dikelilingi oleh bukit dan hutan. Adapun im-plementasi dari pemahaman etika lingkungan di Kampung Naga dalam hal pemeliharaan lingkungan alam secara lebih jelas digambarkan pada tabel berikut.

\section{Tabel 1.}

\section{Implementasi Pemahaman Etika Lingkungan} dalam Pemeliharaan Lingkungan Alam di Kampung Naga

\begin{tabular}{|c|c|c|}
\hline No & $\begin{array}{c}\text { Etika } \\
\text { Lingkungan } \\
\text { Pada } \\
\text { Masyarakat } \\
\text { Kampung Naga }\end{array}$ & $\begin{array}{c}\text { Peranan } \\
\text { Terhadap } \\
\text { Pemeliharaan } \\
\text { Alam }\end{array}$ \\
\hline 1. & $\begin{array}{lr}\text { Keselarasan } \\
\text { hubungan } \\
\text { masyarakat } \\
\text { Kampung } & \text { Naga } \\
\text { dengan } & \text { alam } \\
\text { sekitar dengan } \\
\text { berpaku }\end{array}$ & $\begin{array}{l}\text { Menjaga kawasan } \\
\text { hutan yang } \\
\text { menjadi } \\
\text { penyeimbang dan } \\
\text { menjaga } \\
\text { lingkungan alam } \\
\text { yang menjadi }\end{array}$ \\
\hline
\end{tabular}

${ }^{36}$ Uron (Ketua RT Kampung Naga), wawancara oleh Citra, Kampung Naga Tasikmalaya, Tanggal 17 Juli 2017.

${ }^{37}$ Endut (Masyarakat Kampung Naga), wawancara oleh Citra, Kampung Naga Tasikmalaya, Tanggal 17 Juli 2017. 


\begin{tabular}{|c|c|c|}
\hline & $\begin{array}{lr}\text { pikukuh } & \text { nenek } \\
\text { moyang } & \text { yang } \\
\text { tertuang } & \text { pada } \\
\text { istilah } & \text { leweung } \\
\text { lain } & \text { ruksakeun } \\
\text { tapi } & \text { rawateun } \\
\text { jeung rumateun. }\end{array}$ & $\begin{array}{l}\text { lingkungan hidup } \\
\text { masyarakat } \\
\text { Kampung Naga. }\end{array}$ \\
\hline 2. & $\begin{array}{l}\text { Menerapkan } \\
\text { aturan adat dalam } \\
\text { tata wilayah dan } \\
\text { Kepercayaan } \\
\text { bentuk bangunan } \\
\text { rumah yang harus } \\
\text { sama dengan } \\
\text { yang di bangun } \\
\text { oleh nenek } \\
\text { moyang }\end{array}$ & $\begin{array}{l}\text { Mitigasi bencana } \\
\text { di Kampung } \\
\text { Naga, seperti } \\
\text { mencegah longsor } \\
\text { dan banjir. }\end{array}$ \\
\hline 3. & $\begin{array}{l}\text { Penghormatan } \\
\text { terhadap hutan } \\
\text { yang disakralkan } \\
\text { dan hutan yang } \\
\text { harus dihindari. }\end{array}$ & $\begin{array}{l}\text { Menjaga } \\
\text { sumberdaya yang } \\
\text { terdapat di dalam } \\
\text { hutan, hingga } \\
\text { hutan tetap asri } \\
\text { dan tidak gundul. }\end{array}$ \\
\hline 4. & $\begin{array}{l}\text { Adanya patangan } \\
\text { atau tabu yang } \\
\text { termanifestasikan } \\
\text { oleh kata pamali } \\
\text { yang merupakan } \\
\text { warisan nenek } \\
\text { moyang. }\end{array}$ & $\begin{array}{l}\text { Hal ini membawa } \\
\text { implikasi positif } \\
\text { pada hak dan } \\
\text { kewajiban } \\
\text { komunal dalam } \\
\text { pemeliharaan } \\
\text { sumberdaya alam } \\
\text { bersama-sama. }\end{array}$ \\
\hline 5. & $\begin{array}{l}\text { Pengetahuan lokal } \\
\text { dalam } \\
\text { memanfaatkan } \\
\text { sumberdaya alam } \\
\text { yang diwarisi } \\
\text { nenek moyang }\end{array}$ & $\begin{array}{l}\text { Memelihara dan } \\
\text { menjaga tanaman } \\
\text { yang risa } \\
\text { dijadikan sumber } \\
\text { obat } \\
\text { masyarakat bagi } \\
\text { Kampung Naga. }\end{array}$ \\
\hline
\end{tabular}

Sumber: sumber data dari olah hasil penelitian, 2017.

\section{SIMPULAN}

Masyarakat Kampung Naga memiliki pemahaman etika lingkungan yang cukup intens dalam pemeliharaan lingkungan alam. Pemahaman etika lingkungan Masyarakat Kampung Naga berpacu pada nilai-nilai yang dirumuskan secara sistematis berdasarkan pada warisan nenek moyang mereka. Warisan nenek moyang tersebut digolongkan menjadi dua bagian, yaitu warisan yang tampak (tangible) dan warisan yang tidak tampak (intangible).

Hakikatnya, pemeliharaan alam di Kampung Naga yang berdasarkan etika lingkungan yang khas tersebut mencerminkan hubungan ekologis yang seimbang. Implementasi dari hubungan ekologis tersebut berbuah manis dalam menjaga keseimbangan lingkungan alam. Dimana mitigasi (upaya me-ngurangi resiko) bencana telah diterapkan pada kawasan Kampung Naga seperti mencegah longsor dan banjir, terjaganya keutuhan sumber daya alam, terjaganya fungsi hutan yang merupakan paruparu kehidupan, serta semua makhluk ekologis di wilayah adat tersebut telah sama-sama menaati etika yang disuguhkan oleh ekosentrisme atau deep ecology.

\section{DAFTAR PUSTAKA}

Borrong, Robert P. Etika Lingkungan Hidup dan Perspektif Kristen, dalam Jurnal Pelita Zaman, Vol. 13 No.1. Bandung: Yayasan Pengembangan Pelayanan Kristen, 1998.

Chang, William Moral Spesial. Yogyakarta: Kanisius, 2015.

Imam Suprayogo dan Tobroni, Metodologi Penelitian Sosial Agama, (Bandung: Remaja Rosdakarya, 2003.

Keraf, A. Sonny. Etika Lingkungan Hidup. Jakarta: Kompas, 2010.

Maria, Siti dkk. Sistem Keyakinan Pada Masyarakat Kampung Naga Dalam Mengelola Lingkungan Hidup: Studi Tentang Pantangan Dan Larangan. Jakarta: Depdikbud, 1995.

Setiawan, Hawe. Tanah Dan Air Sunda. Depok: Api Kecil, 2017.

Susilo, Rachmad K. Dwi Sosiologi Lingkungan. Jakarta: Rajawali Pers, 2012.

Wawancara

Ade Suherlin (Kuncen Kampung Naga), wawancara oleh Citra. Kampung Naga Tasikmaaya, Tanggal 21 Juli 2017. 
Endut (Masyarakat Kampung Naga), Uron (Ketua RT Kampung Naga), wawancara wawancara oleh Citra. Kampung Naga Tasikmalaya. Tanggal 17 Juli 2017. oleh Citra. Kampung Naga Tasikmalaya. Tanggal 17 Juli 2017.

Heri (Masyarakat Kampung Naga), wawancara oleh Citra. Kampung Naga Tasikmalaya. Tanggal 21 Juli 2017. 